\title{
ARCHITEKTŪROS POLITIKOS APRAIŠKOS LIETUVOS TARPUKARIO (1918-1940 m.) PERIODIKOJE: TARP REPREZENTACIJOS IR SOCIALINIO TEISINGUMO
}

\author{
Vaidas Petrulis \\ Kauno technologijos universitetas, Architektūros ir statybos institutas, \\ Tuneliog.60,LT-44405, Kaunas, Lietuva, el.paštas:vaidas_petrulis@yahoo.com
}

Itteikta 2009-03-16

\begin{abstract}
Santrauka. Straipsnis skirtas Lietuvos tarpukario laikotarpio (1918-1940) teorinio diskurso analizei. Tekste, remiantis periodikoje publikuotais straipsniais, skirtais architektūros temoms, siekiama pažvelgti ị šio periodo architektūrinès minties palikimą. Dèmesio objektu pasirinkta viena iš svarbesnių architektūrinio diskurso temų - architektūros ir politikos sąsajos. Išskiriami keli to meto spaudoje dominavę architektūros ir politikos sąveikos aspektai: valstybės erdvinès reprezentacijos problematika (kaip globalios, ideologinès politikos apraiška) bei socialinio būsto problematika (kaip lokalios, $\mathfrak{i}$ tiesioginius sprendimus orientuotos politikos apraiška). Nustatyta, kad reprezentacinèje plotmèje dominuojanti teoriné pozicija - „tautinio stiliaus“ paieškos. Socialinei, politizuotai modernizmo teorijai būdingi aspektai daugiausiai reiškèsi menkiau teoretizuotose diskusijose apie „pigių būstų kolonijų“ kūrimą.
\end{abstract}

Reikšminiai žodžiai: tarpukaris, architektūros teorija, architektūros politika, tautinis stilius, pigus būstas, modernizmas.

\section{Ivadas}

Lietuvos tarpukario architektūrologinių tekstų analizè, kol kas gana nauja, Lietuvoje menkai plètota architektūros istorijos tema. Tyrimo objektu tradiciškai pasirenkant vieną ar kitą materialiojo paveldo aspektą, tekstai paprastai pasitelkiami kaip papildymas prie materialiųjų bei ikonografinių šaltinių. Tačiau, kaip pastebi britų architektūrologas Adrian Forty, šiuolaikiniame pasaulyje „architektūra yra trinarè sistema, kuri susideda iš statinio, jo vaizdo (piešinio, fotografijos) ir ji lydinčio diskurso" (2004: 13). Tad ir Lietuvos tarpukario architektūrinio diskurso tyrimai galètu tapti savarankiška architektūros istorijos studijų dalimi. Tai paskatintų architektūrą suvokti kaip integralią kultūros istorijos dalį, o to meto tekstus, kurie yra lietuviškosios architektūrinès savivokos metraštis, kaip integralią kultūros paveldo dalį.

İdomu, kad panašios pozicijos atgarsių galètume rasti ir tarpukario teoriniuose darbuose. Antai A. Jokimas teigia: „,klausimus „kaip pagyvinti kultūrinị gyvenimą Lietuvoje, ką reikia daryti, kad statomi namai būtų gražūs", galima iškelti greta kitų klausimų, susijusių su kitų mūsų kultūros šakų pasireiškimu: „ką daryti, kad būtų paišomi geri paveikslai, kad būtų rašomos geros operos ir kiti teatraliniai veikalai, kad būtų rašomos geros knygos ir t. t.“ (Jokimas 1940: 44). Bendrasis kultūrinis architektūros pradas pabrěžiamas ir Lietuvos atstatymo komisariato (LAK) dokumentuose, pabrèžiant, kad „tautos kultūra pasireiškia per jos gyvenimo būdą" (Kelermileris 1922). Kitaip tariant, kultūrologinis požiūris ị architektūrą vertintinas tiek kaip šiuolaikinè metodologinè nuostata, skatinanti atsigręžti ị tekstus, tiek kaip autentiškas laikotarpio architektūrinès savivokos bruožas. Šiame straipsnyje aptarsime tik vieną šios plačios temos aspektą - architektūros ir politikos santykị, kurị galima interpretuoti kaip vieną ryškiausių architektūrinès kultūros fenomenų.

Užsibrèžus tikslą pažvelgti ị tarpukario architektūrą per architektūrinès politikos pjūvị, visų pirma tenka atsakyti ị klausimą, iš kokios perspektyvos vertinsime patị šios sąsajos fenomeną. Jị galima nagrinèti tiek siaurąja prasme kaip tiesmukai politinę valią 
igyvendinančius architektūros sprendinius, tiek plačiąja prasme, prisilaikant nuomonès, kad „bet kokia erdvès artikuliacija visuomet apima ir galios klausimą tiek, kiek tai reguliuoja sąveikas tarp statinio naudotojų, daro ịtaką jų veikslų laisvei, leidžia jiems tapti tam tikrų stebèjimo ir kontrolès formų objektais" (Markus et al. 2002: 68). Tenka konstatuoti, jog vargu ar įmanoma viename straipsnyje išsamiai išnagrinèti visas tokio sudètingo ir daugiabriaunio fenomeno apraiškas. Tad tekste koncentruojamasi ị architektūrinès politikos apraiškas spaudoje, šiuo kartu nuošaleje paliekant tiek gilesnę teisinès bazès analizę ${ }^{1}$, tiek profesinių bei visuomeninių vienaip ar kitaip su architektūros procesais susijusių organizacijų veiklą, tiek kitas galimas politikos bei architektūros sąveikos formas ir siaurąja, ir plačiąja prasme. Straipsnio tikslas - įvardinti pagrindinius architektūros ir politikos sąsajos aspektus, kuriuos galima įžvelgti šio laikotarpio spaudoje.

\section{Erdvẻ kaip politinis ženklas}

Bene akivaizdžiausia politikos ir erdvès santykio forma - galios reprezentacija. Prabilus apie reprezentatyviąsias architektūros funkcijas, visų pirma reikia atkreipti demesị $\mathfrak{i}$ takoskyrą tarp privatumo ir viešumo. Nors privataus kapitalo kuriamos erdvès taip pat vertintinos per reprezentatyvumo prizmę, šiame straipsnyje koncentruojamasi į visuomeninę architektūros politiką, kurios viena iš ryškiausių formų - tautos/valstybès reprezentacija architektūrinèse erdvėse. Čia pat turètume išskirti ir du šiek tiek skirtingus architektūrinès reprezentacijos aspektus - funkcinę tipologiją ir reprezentatyvumo sąsajas su architektūrinès kompozicijos sprendimais. Viena vertus, tam tikri objektai buvo statomi ir suvokiami ne tik kaip valstybès funkcinių poreikių reprezentantai, tačiau turëjo ir papildomą - tautos kūrimosi, stiprejimo bei pažangos iprasminimo dimensiją. Kitaip tariant, patys objektai kuriami ir, kas ne mažiau svarbu, visuomenei pristatomi kaip turintys ženklinę-simbolinę vertę. Kita vertus, reprezentatyvioji statinio funkcija dažniausiai yra tiesiogiai susijusi su estetiniu architektūros ịprasminimu pasirenkant vienokią ar kitokią stilistiką.

\footnotetext{
${ }^{1}$ Reikia atkreipti dèmesị ị tai, kad nepaisant ilgų diskusijų ir visuotinai pripažinto reikalingumo, pagrindinis architektūrą reglamentuojantis istatymas taip ir nebuvo priimtas, paliekant galioti carinejje Rusijoje veikusị įstatymą. Tai menkina galimybę kalbèti apie aiškiai artikuliuotą valstybès architektūros politiką, kuri būtu igavus ịstatymais ir sprendimais išreikštą formą. Kita vertus tokios valdžios iniciatyvos kaip „mūrinès Lietuvos“ planas be abejonès vertos atskiro išsamaus tyrimo.
}

Erdvinių darinių politizavimo formas galima sąlygiškai grupuoti pagal jų turinio atvirumą. Viena akivaizdžiausių architektūrinio reprezentatyvumo apraiškų - monumentaliosios architektūros objektai, kuriuose visomis įmanomomis priemonemis, kartais netgi peržengiant realias to meto ekonomines bei technines galimybes, siekiama išskirtinumo. Simbolinis potencialas paprastai sustiprinamas ir urbanistiniu dominavimu. Tačiau politinè prasmé čia dažniausiai išreiškiama abstrakčiomis architektūrinèmis formomis, kurios suvokejui ne visuomet tiesiogiai suprantamos ir reikalauja atskiro paaiškinimo. Kitaip tariant, šie objektai nèra visiškai autonomiška komunikacinè sistema ir "tampa kodu, kai sujungiami su sistemomis, kurios yra už architektūros ribų“ (Markus et al. 2002: 8), t. y. prasmingai komunikacijai pasitelkiamas architektūrologinis tekstas. Kur kas tiesmukesnis ir menkiau nuo architektūrinių sprendimų priklausomas politinis erdvès ịprasminimas - smulkiosios architektūros formos (pradedant lozungais ir baigiant paminklais) ar lengvai iššifruojami architektūrinio dekoro elementai. Tokie, R. Venturi žodžiais tariant, „adaptuoti iš egzistuojančių žodynų“ (Theories and Manifestoes of ... 1997: 55) erdvinès aplinkos elementai mūsų aptariamo laikotarpio atveju siejami su Lietuvos valstybingumu ir tautiškumu. Patys būdami simboliniais ar netgi žodiniais tekstais politinị turinị šie objektai atskleidžia be papildomų architektūrinio diskurso priemonių. ${ }^{2}$

Kalbant apie tiesmukas erdvès ir politinio turinio sąsajas, dèmesị visų pirma patraukia tarpukario miestuose ir miesteliuose gana plačiai paplitęs reiškinys, kuri būtų galima pavadinti urbanistinès ir geografinès erdvès nacionalizavimo programa. Gatvèms, aikštėms, sodams, gimnazijoms, netgi miestams ${ }^{3}$ masiškai suteikiami Vytauto Didžiojo ir kitokie politinę prasmę turintys pavadinimai. Ideologinè tokių veiksmų prasmė ypač ryškiai atsiskleidžia palyginus su kitomis, stipriai ideologizuotomis visuomenemis, tarkim Sovietų Sąjunga. Antai S. Grava, kalbejdamas apie sovietinių metų erdvès ideologizavimo būdus, kaip vieną ryškiausių veiksnių pamini „politiškai apgalvotus gatvių, rajonų, aikščių ir kitų viešųjų erdvių pavadinimus“ (Grava 1993: 11). Ne mažiau svarbus ir erdvès dekoravimas politiškai įprasmintais ir lengvai atpažịstamais ženklais. Be to, švenčių metu

\footnotetext{
${ }^{2}$ Abu principai neretai vienas kitą papildo. Bene iliustratyviausias pavyzdys - „socialistinio realizmo“ architektūra.

${ }^{3}$ Pvz., 1934 m. pastačius paminklą V. Kudirkai, Naumiestis pervadintas Kudirkos Naumiesčiu.
} 
„miestų ir miestelių i̇staigos, visuomeniniai pastatai, centrinèse gatvèse įsikūrusios parduotuvès pasipuošdavo ne tik tautinemis vèliavomis, žalumynais, kaspinais, spalvotomis lempelèmis, bet taip pat valstybès vadovų ir Lietuvos praeities didvyrių atvaizdais"(Jankevičiūte 2002: 46). Galime aptikti užuominų ir apie tiesioginès politinès agitacijos atvejus, kurie, be kita ko, akcentuojami ir spaudoje. Antai aprašant kelionę i Kèdainius atkreipiamas dèmesys, kad Kèdainių geležinkelio stotį puošęs "puikus plakatas“ su užrašu „Ei, pasauli, mes be Vilniaus nenurimsim!“ (Uždavinys 1938). Šiuo aspektu įdomus ir Kauno karininkų ramovès pagrindini iejjimą vainikuojantis trijų herbų (Kauno, Klaipedos ir Vilniaus) motyvas, spaudoje išaiškintas kaip karininkų priesakas, kad „rūmų šeimininkai saugoja mūsų teritorijos sienas ir niekuomet be Vilniaus nenurims“ (Ramovès ... 1937). Vilniaus temą galima atsekti netgi kryžių, kurie, anot A. Varno, „yra savo rūšies mūsų piramidès“ (1925: 81), statyboje: „pieno perdirbimo bvès Alančiu punkto gyventojai, minèdami to punkto dešimties metų sukaktị, pastatė Alančių kaime gražu Vilniaus kryžių“"(Nameliai ... 1937: 11). Tad galima daryti išvadą, jog smulkieji, tekstualiai atviri bei lengvai suprantami erdvess politinio ịprasminimo atvejai buvo gana intensyvus reiškinys, tam tikrais atvejais sulaukęs paminèjimų ir spaudoje.

Kaip būdingą atviro erdvès politiškumo pavyzdi būtina paminèti ir paminklus bei reprezentacines aikštes. Visais laikotarpiais tai buvo populiari ir iliustratyvi forma architektūrinèmis-urbanistinèmis priemonèmis išreikšti politinę valią. Ne išimtis ir tarpukario Lietuva. Paminklai intensyviai statyti tiek laikinojoje sostineje (vien ko vertas Vytauto Didžiojo paminklas, stovejęs Panemuneje), tiek mažuosiuose miesteliuose. Vytautui Didžiajam, nepriklausomybès, žuvusiems nepriklausomybès kovose atminti bei kitoms progoms skirti paminklai religini gyventojų sąmoningumą akivaizdžiai siekè papildyti tautiniu. Neužmiršta ir politinèms bei reprezentacinèms reimėms skirtu paradiniu aikščiu būtinybė: „aikštè Žaliajame Kalne prie Aušros gatvès yra manoma paskirti kariuomenès paradams ir viešiem susirinkimams“"(Jokimas 1924: 8)4. Senosios aikštès taip pat neretai „persispalvino naujomis ideologinemis prasmèmis“ (Kančienė 2006: 72). Mažesniuose miesteliuose šalia paminklų taip pat neretai aptiksime ir didesnio ar mažesnio mastelio skverus, kurie tarnavo tam pačiam tikslui. Visgi tokios gan tiesmukos poli-

\footnotetext{
${ }^{4} 1924$ m. A. Jokimo ir F. Vizbaro parengtas aikštess suplanavimo ir sutvarkymo projektas taip ir nebuvo igyvendintas (Kančienè 2006: 76)
}

tikos apraiškos erdveje, periodineje spaudoje dažniau pasirodydavo tik kaip fakto konstatavimas, neišprovokuodavęs platesniu teorinių diskusijų. Kitaip tariant, šių erdvių reikšmès pateiktos atvirai, suvokiamos tarsi savaime, nepriklausomai nuo jas lydinčio diskurso.

Monumentaliosios architektūros politinis itprasminimas neatsiejamas nuo paaiškinančio teksto: „pašventintieji [Prekybos, pramonès ir amatų] rūmai galès pas mus būti tam tikru simboliu. <...> namai buvo pradèti statyti, pastatyti ir iškilmingai atidaryti tik $<\ldots>$ pradejus prekybą, pramonę ir amatus Lietuvoje tvarkyti naujais - valstybiniai korporatyviniais pagrindais" (Valstybès ... 1939: 1). Tiesa, skirtingai nuo griežto totalitarinio režimo šalių, šios politinès reikšmès spaudoje galèjo būti ir kvestionuojamos: „reiktų pagalvot, ar tos sumos (bent iš dalies), kurias dabar išleidžiame Darbo Rūmams ir jų moderniems pastatams ir visokiems kultūrklubams, nevertètų paskirti namelių statybai. <...> kol žmogus skursta, tai jam neįdomu nei kultūrklubai, nei puikios salès" (Kalakauskas 1938). Visgi tiek argumentai „už“, tiek „prieš“ patvirtina esminę prielaidą - statinys čia reikšmingas ne tik savo architektūriniu pavidalu, bet ir platesnemis, glaudžiai su politika susijusiomis prasmemis. Tokios monumentaliosios architektūros ir politinès sąveikos atpažistamos visu tarpukario laikotarpiu įvairiausiomis formomis, pradedant nuo siūlymų statyti muziejų Nemuno ir Neries santakoje (Dainius 1929) ar Vyriausybès rūmus ant Vytauto kalno (Jokimas 1924: 8) ir baigiant diskusijomis apie igyvendintus įvairius reprezentacinius valstybės objektus, besikoncentruojančius naujai kuriamoje sostinèje Kaune. Svarbiausiais tokio pobūdžio statiniais galètume laikyti Vytauto Didžiojo muziejų, Prisikèlimo bažnyčią, Karininkų ramovę, Prekybos, pramonès ir amatų rūmus, iš dalies ir Lietuvos banko pastatą. Politinè šių objektų reikšmè plačiai nušviesta to meto spaudoje (Petrulis 2008:41-43). Su politiniu kontekstu sietina ir diskusija dèl urbanistiškai ne ką mažiau reikšmingo statinio - Kauno soboro - nugriovimo ${ }^{5}$.

Tačiau architektūrologiniu požiūriu įdomus ne tik šiu statinių atsiradimo bei motyvavimo faktas, bet ir būdai, kaip šis politinis reprezentatyvumo uždavinys buvo igyvendinamas, kitaip tariant, kokia stilistine išraiška buvo pageidaujama ir naudojama. Čia galime išskirti

\footnotetext{
$\overline{5}$ İdomu atkreipti dèmesị i tai, kad su Rusijos įtaka tapatintos taip pat ir bendrosios miestų bei miestelių negerovès, nešvara: „prieškarinè rusu „,bezalaberšina“ ir garsusis rusiškasai „purvynèlis“ (bolotco) dar ir ligi šiai dienai mums taip gardžiai patinka, jog mes be jų apsieiti negalime“" (Susirūpinkime ... 1932: 4).
} 
dar vieną architektūrinio diskurso potemį - diskusijas dèl stilistikos, tinkančios reprezentuoti valstybę.

\section{Stilius kaip reprezentatyvumo prielaida}

Vienoks ar kitoks visuomeneje vyraujantis architektūros grožio, architektūrinès harmonijos suvokimas kartu suteikia galimybę pasirinkti tinkamas politinei reprezentacijai formas. Ne paslaptis, kad dauguma reprezentacinių objektų tiek laikinojoje sostineje, tiek kituose miestuose ir miesteliuose buvo statomi vadovaujantis senąja, jau Periklio laikų Atènuose ištobulinta architektūros grožio formule - „harmonija, kaip visų dalių proporcingumas, geometrinis tobulumas ir ornamentas, kaip kažkas papildomo, kaip „grožio pagerinimas" (Norberg-Schulz 1993: 128).

Pritarimą istorizmo elementams naujojoje architektūroje galime atpažinti ir viename kitame atsiliepime apie reikšmingesnius to meto statinius. Antai 1922 m., komentuojant vieno iš svarbesnių objektų, Valstybinès spaustuves, konkurso projektus rašoma: „fasadas patiektas modernizuotame vokiečių klasicizmo stiliuje ir trobėsis suteiktų grožès Kauno miestui“"(Valstybinès ... 1923: 25); žavimasi ir „paauksuotais tautiniais ornamentais $\langle\ldots>$, milžiniškos žvaigždès gipsiniais spinduliais, lelijų lapeliais“" (Kauno ... 1923: 4) Kauno miesto teatre. Kiek įdomiau istorizmą teoriškai įprasmina M. Songaila, kai aprašydamas savo projektuotus Fizikoschemijos instituto rūmus teigia, jog siekęs sukurti statinị, „kad būtų galima universiteto studentus gyvais pavyzdžiais supažindinti su klasiškomis formomis“" (Songaila 1933: 468). Tačiau tai kartu liudija, jog pats architektas suvokia, kad istorinių architektūros formų naudojimas jau neatitinka laikmečio dvasios. Savitą istorinių formų panaudojimo argumentaciją pateikia ir V. Landsbergis-Žemkalnis, Kūno kultūros rūmuose siekdamas „sujungti vienam pastate du dalykus, dvi formas: klasiką, pirmajji didị fiziškos kultūros pionieriu (Graikija), su mūsu laikais“" (Landsbergis 1931: 113). Atskirų argumentacijos už klasikinę manierą atvejų atrastume ir kituose straipsniuose. Visgi, nepaisant minètų pavyzdžių, galime užčiuopti tam tikrą teorijos ir praktikos nesutapimą. Praktikoje nepriklausomai nuo funkcinio tipo ir laikmečio (iškalbingas pavyzdys Karininkų ramoves pastatas, suprojektuotas 1935-taisias) bene populiariausias sprendimas siekiant objektui suteikti reprezentatyvumo - daugiau ar mažiau supaprastintas istorizmas, o spaudoje - priešingai. Čia kur kas dažniau sutiksime publikacijų, kuriose svarstoma apie būtinybę istorines architektūros formas keisti naujomis. Tad kokios šio prieštaringumo priežastys?
Viena vertus, eklektiniai ir istorizmo architektūros pavyzdžiai tiesiogiai siejosi su senąja politine santvarka. Tad „skolinimas“ iš „,senobès rusų tradicijų, [kai] imama net pačioj Rusijoj, net jau prieš karą, prakeiktą ir inbiurusị statybos būdą" (Dubeneckis 1925: 93), toli gražu neatrodè patrauklus bei puoselètinas teorineje mintyje. Kita vertus, visuomenèje vyraujantis architektūros grožio suvokimas dar toli gražu nèra bauhauzinis. „Visi naujieji namai be jokių pagražinimų, be bendro stiliaus. Gal tai ir yra moderniška, bet vis dèlto miesto nepuošia“ (Nemo 1932) - rašoma populiariojoje spaudoje. Dalis periodikoje pasirodančių straipsnių, ypač iliustruojančių ne architektūros specialistų nuomonę, apskritai abejoja moderniąja architektūra, kaip estetine vertybe, ir pasigenda ,tikrojo architektūrinio stiliaus“: „Ar stiliaus vieningumą gali atstoti kitas vieningumas - grynai racionalinis, technikinis, kuris viešpatauja pritaikomojoj šių dienų architektūroj? <...> Ar standartizuotas vieningumas gali pakeisti intymų, dvasini vieningumą, kuriuo pasižymėjo visi didieji praeities stiliai?" (Ar atgimsta ... 1935: 202). Gana žaismingai vyraujantị architektūros mentalitetą apibūdina ir 1935 m. Kaune lankęsis estų architektas Hanno Kompus: „Kauniečiai, atrodo, turi palinkimą ir talentą ị didelị dekoratyviškumą, pasakyčiau, net paradiškumą. Tat reiškiasi net uniformoje: jau Lietuvos stotyse policininkai efektiškai krenta ị akis savo kutosais, aukštais šalmais $\langle\ldots\rangle$. Šis džiaugsmas dekoratyviškumui reiškiasi ir fasaduose, balkonuose, karnizuose ir kituose architektūros elementuose, prie ko prisideda dar plastiškieji atvaizdavimai herbuose, biustuose, medaliuose ir t. t. “ (Iš senos ... 1935: 5).

Tad nors suinteresuotoji Lietuvos visuomenès dalis turèjo galimybę gana greitai, pernelyg neatsilikdama nuo Europos susipažinti su novatoriškiausiomis architektūros teorijomis, nors architektai (V. Švipas, K. Reisonas, S. Stulginskis ir kt.) viešai deklaravo mintis, artimas XX a. pirmosios pusės modernistų principams, senąją architektūrą laikydami „knaisiojimu visokių Liudvikų kapinèse“ (Švipas 1927: 332), tačiau kai prabylame apie reprezentatyvumo sampratas, funkcionalizmas greičiau laikytinas reta išimtimi. Visuomenès mentalitete ịsišaknijęs architektūros reprezentatyvumo tapatinimas su dekoratyvumu išlieka pakankamai stipriu argumentu per visą tarpukario laikotarpi. Puiki iliustracija - 1939 m. planuojamas statyti Valstybès rūmų kompleksas. Architektūrinès estetikos prasme konkurso dalyviams buvo išsakytas aiškus reikalavimas: „pastatų architektūroje pageidaujama laikytis klasikinès dvasios“(Valstybès ... 1939: 8). 
Tačiau prisimenant neigiamas istorizmo konotacijas, galima tiketis kažkokios savitos teorinès pozicijos, iprasminančios reprezentatyvumo paieškas ir kartu, kiek tai įmanoma, atspindinčios architektūrinį visuomenès mentalitetą. Savotiška išeitimi tampa „tautinis stilius", apie kurio kūrimą spaudoje nuvilnija itin plačios diskusijos. Ši, istorizmo ir liaudies meno motyvus supynusi stilistika tampa bene aiškiausiai Lietuvos politinius principus ịkūnijančia architektūros forma. Kaip pastebi D. Mačiulis, po 1926 m. perversmo „minimali lietuvybès sauga numatè lietuvių kalbos puoselèjimą, o maksimali reikalavo tautinių mitų ir simbolių" (2005: 193). Architektūrinè raiška, kaip vienas svarbiausių materialiosios kultūros formavimo elementų, čia užèmè neabejotinai svarbią vietą. Tą patvirtina ir architektūrai skirti straipsniai, iš kurių galima susidaryti gan tvirtą prielaidą, kad retorika, puoselëjanti „tautinio stiliaus" paieškas, iš esmès atspindi bendrą patriotini diskursą ir tiesiogiai siejasi su politiniais tikslais. Panašius imperatyvus kūrejjams rasime tiek architektūroje ir urbanistikoje (Petrulis 2008), tiek daileje (Jankevičiūtè 2002), tiek apskritai bet kurioje kultūrinès veiklos srityje.

Šioje vietoje derètų akcentuoti, kad „tautinio stiliaus" atveju svarbesnis ne išskirtinis funkcinis tipas, bet stilistinè raiška. Siekiama, kad ji taptų universali visiems objektams. Taigi politine argumentacija iš reprezentatyvių funkcinių tipų perkeliama ir ị kasdienybę. Idejjine prasme tai galima interpretuoti kaip tam tikrą sąsają su modernizmu.

\section{Architektūra kaip socialinis projektas}

Suvokiant modernizmą kaip turintị „Atėnų chartijos“ dvasios požymių, vienas iš svarbiausių idèjinių modernizmo inspiracijos šaltinių - dèmesys socialiniam aspektui. Tiesa, reikia neužmiršti, kad pamatinis „Atenuc chartijos" tikslas - pertvarkyti chaotiškos XIX a. urbanizacijos pasekmes. Lietuvoje šios problemos kiek menkesnès, tad ir teoriniai bei politiniai lūkesčiai, o ir praktiniai miestų plètros tikslai yra kiek kitokie, dažniau besisiejantys su kasdienio miesto modernejimo (vandentiekio, šaligatvio tiesimas ir pan.) bei švarejjimo refleksijomis.

Net ir vienas iš svarbiausių modernizmo principu daugiabučių statyba - Lietuvos spaudoje neretai priimamas kritiškai, kaip ,,ardantis miesto architektonini vaizdą" (Daugis 1932), o apgyvendinimo siekiama mažaaukščiuose gyvenamuosiuose namuose. Didesnieji miestų darbininkų namai, netgi sparčiai augančioje laikinojoje sostinëje, kurią kamuoja butų krizė, teoriškai planuojami tik kaip 4-12 butų (Yla 1937). Nepaisant to, jei bandytume apibendrinti vienaip ar kitaip su modernumu ir socialine politika susijusią tarpukario spaudą, tekstus, kuriuose svarstomi apgyvendinimo procesai, turètume išskirti kaip vieną aktualiausių bei plačiausiai diskutuojamų temų. Tuo pat metu šie straipsniai iliustruoja ir Lietuvos architektūrinès minties modernèjimo kelią. Publikacijose diskutuojama apie miesto raidą pritaikant ji prie socialinių reikmių, kovojant su skurdu (Korsa 1936a: 3). Akcentuojama, kad sprendžiant butų klausimą pakankamai didelį vaidmenį gali atlikti „susisiekimo ir susižinojimo priemonių ištobulinimas“ (Miestų ... 1935: 1), t. y. pasaulio modernèjimas.

Prisiminus F. Jameson teigini, kad politika architektūriniame kontekste gali būti suprantama dvejopai: kaip specifiška, vietinè, empirinè veikla ir kaip „politika globaliąja prasme" (Jameson 2005: 243), diskusijose apie „pigių butų kolonijas" pastebimas itin ryškus empirinis politikos akcentas. Vienas išiliustratyvių pavyzdžių - 1932 m. Kauno miesto burmistro J. Pikčilingio viešai deklaruotas užsakymas miesto inžinieriui sudaryti „bandomąji bendrų bruožų projektą tokių namų, kuriuose būtų su atitinkamais patogumais šeimoms gyventi butai, kurių nuoma būtų 50 litų per mènesį, ir kad vis dèlto tos pajamos padengtų namų išlaikymo išlaidas, amortizaciją ir įdèto kapitalo procentus" (Pigių ... 1932: 3). Čia pat spaudoje gautas atkirtis - ,jei tie patogumai susidètų tik iš vandentiekio ir centralinio šildymo, tai labai tenka abejoti, ar imant tokio didumo nuomą, kad ir už mažiausią buteli, gaunamos pajamos padengtų namų išlaikymo išlaidas, amortizaciją ir ịdèto kapitalo procentus"(Karigalis 1932) - leidžia daryti prielaidą, kad tokie burmistro teiginiai nemaža dalimi tapatintini su politine retorika. Panašaus pobūdžio diskusijų spaudoje galètume rasti pakankamai daug ir ivvairiuose leidiniuose. Argumentuojama tiek žvelgiant iš darbininku pusès: „darbininkija gali ir turi pageidauti griežtesnio valstybès ịsikišimo, jeigu turtingieji patys nenori susitvarkyti“ (Kalakauskas 1938); tiek pigių butų statybą siekiat pagrịsti darbdavių interesais: „iš praktikos yra nustatyta, kad darbininkai ivertina fabrikų pastangas gerinti jų būklę ir už tai stengiasi atsilyginti sąžiningumu, stropumu, darbingumu ir aplamai to fabriko, kuriame jie dirba, nuoširdžiu interesų dabojimu" (Nameliai ... 1937: 12); tiek svarstant ekonominio pelningumo galimybę: „nèra vilties tikètis, kad pas mus galètų ísisteigti privatinès biznio bendrovès, kurios galètų imtis pigiųjų butų statybos" (Korsa 1936a: 2); tiek bandant atrasti realias politinio veikimo formas: „butų klausimo reikalu vyriausybių žygius galima būtų suskirstyti ị trijų rūšiu priemones: 
a) butų ir jų sanitarijos įstatymų leidimas, b) butų statyba ir c) butų sanitariné priežiūra“ (Dagys 1931); tiek pristatant užsienio patirtį - pradedant Anglija ar Vokietija ir baigiant Švedija ar sovietine Rusija.

Tačiau tenka pripažinti, kad visas šis daugiau ar mažiau politizuotas tekstų srautas menkai teatspindejo realius apgyvendinimo procesus. Kai spaudoje prabylama apie esamas darbininkų gyvenimo sąlygas, matome gana toli nuo modernybès atitrūkusią situaciją. Vienas iš pavyzdžių - „pigių butų kolonijos“ Kauno tvirtovès fortų kazematuose su „tamsiais ar pustamsiais koridoriais, kuriuose yra pavojingi šuliniai“ (Pigiųjų ... 1932: 4). Tad nepaisant to, kad moderniai irengtos "pigių butų kolonijos" buvo vienas iš dažnai naudojamų politinès retorikos elementų, kad „miesto vadovybe yra pasiryžusi panaikinti buvusias ligi šiol Kauno pakraščiuose senas pigių butų kolonijas, kurios yra virtusios daugiau nuodemių lizdais negu gyvenamaisiais namais" (Kaip ... 1933: 3), šie pareiškimai ar svarstymai liko tik architektūrinès ir politinès minties paveldu. Realūs architektūrinès politikos veiksmai, berods, kur kas akivaizdesni kuriant reprezentacinius statinius, planuojant naujas Rotušès (Vileišis 1939) ar Vyriausybès rūmų (Valstybès ... 1939: 5) statybas.

Tiesa, žinome ir apie keletą progresyvesnių pavyzdžių. Sostinèje, Kaune, būta pavienių paprastos, dažniausiai medinès statybos projektų: „laikotarpy pusantro mènesio Žaliajam Kalne prie Darbininkų gatvès išaugo šeši didoki namai, skiriami biednuomenei ir bebutininkams valdininkams apsigyventi“" (Nauji ... 1924: 3). Neminint kooperatinių namų, kurie taip pat „buvo standartizuojami, todèl ekonomiškesni ir labiau prieinami vidutiniams valdininkams" (Kančienè 1988: 116), atkreiptinas demesys ir ị architektūriškai kiek išraiškingesnius darbus: S. Kudoko projektuotą pigių butų koloniją K. Petrausko gatvejje (1934 m.) ar pagal I. Trakmano projektą pastatytą pigių butų koloniją Griunvaldo gatvèje (1936 m.). Sekant pastaruoju projektu, 1940-aisiais planuota „pradeti darbininku butų statybą ir kituose miestuose: Vilniuje, Šiauliuose, Panevėžyje, Marijampoleje ir kitur" (Darbininkų ... 1940: 227). Su socialinio būsto programomis susiję ir specifinèms grupèms skirti projektai, kaip antai Karo invalidų bendrabutis K. Donelaičio g. 75a, Kaune (1936 $\mathrm{m}$., inž. Acus-Acukas), ar Žaliakalnio senelių prieglauda Aukštaičių g. 10, Kaune (1939 m., arch. K. Reisonas) (1 pav.).

Žvelgdami per teorinès minties prizmę, galètume atkreipti dèmesí, kad nei vienas iš minètų pavyzdžių nevisiškai ịkūnijo standartizacijos principus ar modernistinę bauhauzinę ideologiją apie „fundamentalų pri-

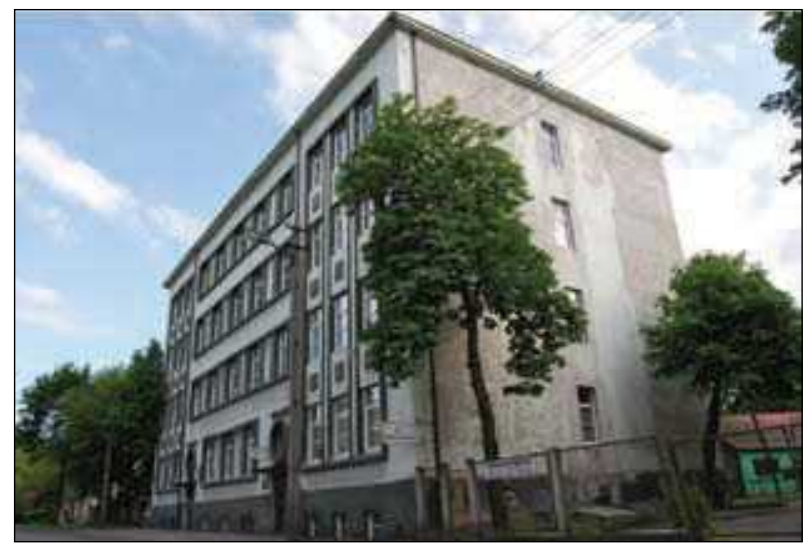

1 pav. Buvusi senelių prieglauda Kaune, Aukštaičiu g. 10 (arch. K. Reisonas), $1939 \mathrm{~m}$.

Fig. 1. Former nursing home in Kaunas, 10 Aukštaičiai st (arch. K. Reisonas), 1939 m.

klausymą nuo technologinès formų kalbos" (Asendorf 2006: 80). Priešingai - šios nuostatos traktuojamos kaip svetimybè. Tarkim, aptariant naujai kylantị darbininkų miesteli Klaipėdoje, kritikuojamas tiek standartinių namelių panašumas, tiek „savotiškas vokiškas stilius, [kuris] juos daro lietuviui nuobodžius“. Galima manyti, kad teigiamu pavyzdžiu būtų palaikyta vienokia ar kitokia „tautinio stiliaus“ apraiška, juoba kad atkreipiamas dèmesys, jog „,naujuose namuose ịsigyvena lietuviai, kurie suvokietintai Klaipedai turi auklejamosios reikšmès. Tai ir aplinkumą jiems reikia padaryti lietuviškesnę" (Klaipedos ... 1938: 3). Turint galvoje taip ir nedavusias apčiuopiamesnių rezultatų ,tautinio stiliaus" paieškas, mediniai namukai (dar $1922 \mathrm{~m}$. pateikti E. Peyerio „Panemunès būstinès“ projekte ar $1925 \mathrm{~m}$. leidinyje „Lietuvių statybos ir puošybos pavyzdžių albumas"), kurie, anot autoriaus, galèjo „būti pavyzdingas ekonominès konstrukcijos ir estetikos žvilgsniu“" (Peyeris 1922) (2 pav.), greičiausiai būtų buvę priimti kur kas šilčiau.

Analizuojant kasdienių funkcinių tipų bei politikos sąsajas, derètų prisiminti ir J. Minkevičiaus pastabą, kad „nepriklausomos Lietuvos valstybés politika buvo grindžiama trimis pagrindiniais prioritetais $\langle\ldots\rangle$ : gynyba, švietimas ir ūkio reformos <...>. Dèl to sutelkus visus įmanomus materialinius finansinius išteklius buvo projektuojamos naujos kareivinès, pradinès mokyklos, gimnazijos, specialios mokyklos, universitetas, sveikatos apsaugos ir sporto objektai, geležinkelio stotys, pieninès ir daug kitų ūkinès paskirties statinių" (2001: 90-91). Tačiau spaudoje plačiau atsispindintis architektūros ir politikos ryšys visų pirma sietinas su 


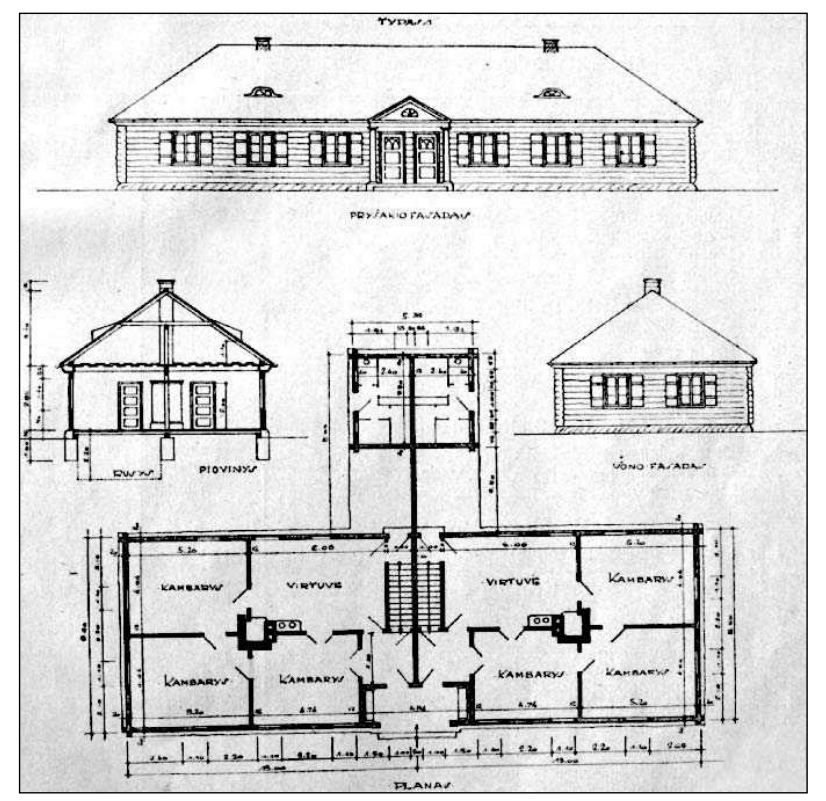

2 pav. Dvieju šeimų tipinio medinio namo projektas Panemunès gyvenvietei (arch. E. Pejeris), $1922 \mathrm{~m}$.

Fig. 2. Project of two-family wooden house for Panemunè neighborhood (arch. E. Pejeris), $1922 \mathrm{~m}$.

gyvenamosios architektūros problemomis. Nepaisant to, kad politinès-socialinès Modern Movement vertybès siekiant visuotinés gerovès be gyvenamojo būsto neatsiejamos ir nuo „valstybès valdomos sveikatos apsaugos bei mokyklų" (Stites 1989: 23), nepaisant to, kad Lietuvoje tarpukario laikotarpiu mokyklų statybos mastas gana įspūdingas, jei žvelgsime per idèjinę prizmę - ryškesnio teorinio pamato šie reiškiniai neigauna. Vargu ar Lietuvoje galètume atpažinti tokių radikalių idejju, kaip tarkim to meto socialistineje Rusijoje, kurioje laikoma, kad „vaikų auginimas ir auklëjimas bus pavestas viešoms ịstaigoms“ (Naujoji ... 1931: 2), idant aktyviai dirbti galetu ir moterys. Lietuvos spaudoje pristatant švietimo sistemai skirtus objektus, kaip ir kitais atvejais, didesnę reikšmę turèjo tautinis patriotinis diskursas. Antai V. Landsbergis, norèdamas išryškinti naujai projektuojamo stadiono privalumus, pabrèžia, kad „Fiziško auklèjimo rūmai, auklèdami sveikus tautos papročius, mokydami tobulinti fizišką patvarą ir sveikatą, turès praskinti mūsų plačioje visuomeneje naujus gyvenimo takus" (Landsbergis 1931). Akivaizdu, tai daugiau su reprezentacine nei su socialine politika susieti pastebejjimai.

\section{Išvados}

1. Apibendrinant Lietuvos tarpukario periodikoje atpažistamas architektūros ir politikos sąsajas galima išskirti dvi problematines grupes. Viena vertus, tekstuose atsiskleidžia valstybingumo įtvirtinimo laikotarpio aktualijos, glaudžiai susijusios tiek su instituciniu (sostinę perkèlus ị Kauną būtina sukurti šiai funkcijai pritaikytą architektūrinę infrastruktūrą), tiek su politiniu reprezentaciniu (ivvairialypiškai išreikštas tautinio pasididžiavimo jausmas) aspektais. Kita vertus, tarpukaris neatsiejamas nuo įvairialypių modernizacijos procesų, kurie spaudoje atsiskleidžia per miesto funkcinès bei socialinès raidos tematikas.

2.Reprezentatyvusis statinių pradas pasireiškè tiek per išskirtinę, valdžios tikslus ịkūnijančią funkciją, tiek per tinkamus stilistinius sprendimus. Stilistinejje plotmejje reprezentaciné valstybès ideologija spaudoje visų pirma tapatinta su „tautinio stiliaus“ paieškomis. Modernioji architektūra, kuri dar nèra kanoniné, kartu nèra tapusi ir galios demonstravimo įrankiu. Svarbiausi valstybinès paskirties statiniai, nors ir nebūdami „tautinio stiliaus" pavyzdžiais, taip pat sulaukdavo tekstų, skatinančių įžvelgti tuose statiniuose pažangos, politinio stabilumo ir panašius motyvus.

3. Bendrieji visuomenès modernèjimo procesai neišvengiamai inspiravo ir tam tikrus socialinius debatus, kurie gan glaudžiai siejasi su bendrąja modernizmo paradigma. Nors ir nebūta tarptautinio lygio architektūros meistrų, ịkūnijančių „herojiškąji periodą“, nors ir nesukurta savita moderniosios architektūros teorija, tačiau atkreiptinas dèmesys ị nemažą architektūrinès spaudos tekstų dalị, kuri skirta socialinio būsto klausimams. Šiuos tekstus galima interpretuoti kaip lokalios, $\mathfrak{i}$ tiesioginius sprendimus orientuotos architektūros politikos apraiškas. 


\section{Literatūra}

Ar atgimsta architektūra? 1935. Židinys XXI(2): 202-203.

Asendorf, C. 2006. The Bauhaus and the World of Technology - Work on Industrial Culture?, in Bauhaus, ed. by J. Fiedler. Cologne: Könemann, 80-88.

Dagys, J. 1931. Miestų statybos ir butų reikalai, Savivaldybé 3(94): 6-10.

Dainius, V. 1929. Keletas žodžių dèl besiartinančio D. L. K. Vytauto mirties 500 metu jubiliejaus, Lietuvos aidas 145(629): 5.

Darbininkų bloko Kaune, Griunvaldo g. projektas. 1940. Savivaldybe 7-8(66-67): 227-229.

Daugis, P. 1932. Musų „dangorèžiai“, Dienos naujienos 155(377): 2.

Dubeneckis, V. 1925. Apie mūsų architektūrą, Baras 1: 89-95.

Forty, A. 2004. Words and Buildings: a Vocabulary of Modern Architecture. London: Thames and Hudson. 335 p.

Grava, S. 1993. The Urban Heritage of the Soviet Regime: The Case of Riga, Latvia, Journal of the American Planning Association, 59(1): 9-30.

Yla, S. 1937. Darbininkų namai. Kaip šis klausimas sprendžiamas pas mus ir kitur, XX amžius 123(281): 5.

Iš senos rusų ịgulos gūžtos išaugo moderniškas miestas: labai idomus svetimšalio architektoriaus žodis apie Kauno statybą. 1935. Lietuvos aidas 142(2405): 5.

Iškilmingai atidaryti - pašventinti Prekybos, Pramonès ir Amatų Rūmų namai. 1939. Lietuvos aidas 80(4482): 1.

Jameson, F. 2005. Is Space political?, in Rethinking Architecture. A Reader in Cultural Theory, ed. by N. Leach, 2 ed. London: Routledge, 242-255.

Jankevičiūtè, G. 2002. Dailè kaip politikos kalba. Lietuva 1918-1940, Menotyra 2(27): 46-55.

Jokimas, A. 1924. Apie Kauno miesto planą, Savivaldybe 8-9(15-16): 6-9.

Jokimas, A. 1940. Apie Kauno miesto statybą, Technika ir ūkis 3(36): 42-45.

Kaip tvarkoma laikinoji sostinè. 1933. Dienos naujienos 167(687): 3 .

Kalakauskas, V. 1938. Trūksta darbininkams butų, Darbininkas 32 (971): 1.

Kančienė, J. 1988. Racionalizmas Kauno tarpukario laikotarpio gyvenamuosiuose namuose (1918-1940), Lietuvos TSR architektūros klausimai IX: 106-122.

Kančienè, J. 2006. Laikinosios sostinès reprezentacinès aikštès, Archiforma 3(35): 72-80.

Karigalis, A. 1932. Svajonès apie pigius butus, Dienos naujienos 5(228): 2 .

Kauno miesto teatras. 1923. Statybos menas ir technika 2(5): $3-5$.

Kelermileris, A. 1922. Prakalba, Statybos menas ir technika 1: 3.

Klaipèdos darbininkams statomas atskiras miestas. 1938. Darbininkas 35(974): 3.

Korsa, K. 1936. Darbininkų butų kolonijų reikalas Lietuvoje, Darbas 17(23): 2.
Korsa, K. 1936. Kaip turètų būti tvarkomas darbininkų butų kolonijų reikalas, Darbas 18(24): 3.

Landsbergis, V. 1931. Fiziško auklejjimo rūmai, Fiziškas auklèjimas 2: 109-114.

Lietuviu statybos ir puošybos pavyzdžiu albumas. 1925. Kaunas: Vidaus reikalų ministerijos statybos inspekcijos leidinys. $96 \mathrm{p}$.

Mačiulis, D. 2005. Valstybès kultūros politika Lietuvoje 1927-1940 metais. Vilnius: Lietuvos istorijos instituto leidykla. $302 \mathrm{p}$.

Markus, T. A.; Kameron, D. 2002. The Words Between the Spaces. London: Routledge, $190 \mathrm{p}$.

Miestų plètimas ir darbo žmonès. 1935. Darbo Lietuva 3: 1.

Minkevičius, J. 2001.Valstybès politikos atspindys Lietuvos architektūroje 1918-1940 m., Archiforma 1: 87-94.

Nameliai „Maisto“ darbininkams. 1937. Ūkininko patarëjas 49(478): 12

Nauji namai. 1924. Lietuvos žinios 289: 3.

Naujoji socialistinių miestų statyba. 1931. Dienos naujienos 59: 2 .

Nemo. 1932. Kauniškès pastabos, Lietuvos aidas 168(15483): 5.

Norberg-Schulz, C. 1993. Meaning in Western Architecture. New York: Rizzolli. 229 p.

Pastatè Vilniaus kryžių. 1937. Ūkininko patarejjas 49(478): 11.

Peyeris, E. 1922. Panemunès būstinès projektas, Statybos menas ir technika 2: 3-10.

Petrulis, V. 2008. Erdvinès lietuvių tautinio stiliaus politikos projekcijos 1918-1939 m., Meno istorija ir kritika 4: 35-48.

Pigių butų kolonijos klausimas Kaune. 1932. Lietuvos aidas 3(1378): 3 .

Pigiųjų butų kolonijos. 1932. Lietuvos aidas 137(1512): 4 .

Ramovès Rūmai. 1937. Kardas 8(262): 187-192.

Songaila, M. 1933. Vytauto Didžiojo universiteto FizikosChemijos institutas, Technika 7: 459-500.

Stites, R. 1989. Revolutionary Dreams: Utopian Vision and Experimental Life in the Russian Revolution. New York, Oxford: Oxford University Press. 307 p.

Susirūpinkime provincijos kultūrinimu. 1932. Lietuvos aidas 26(1401): 4 .

Švipas, V. 1927. Architektūros reikalu, Kultūra 7-8: 329-334.

Theories and Manifestoes of Contemporary Architecture. 1997. Ed. by C. Jencks; K. Kropf. New York, Weinheim, Brisbane, Singapore, Toronto: Academy editions. 312 p.

Uždavinys, V. 1938. Per Jonavą, Kèdainius ị Panevėžį, Darbas 1(293): 8.

Valstybės rūmų statybos projektas. 1939. Lietuvos aidas 51 (4453): 8.

Valstybinès spaustuvès projektu konkursas. 1923. Statybos menas ir technika 1(4): 25-27.

Varnas, A. 1925. Lietuvių kryžiai, Baras 5: 81-83.

Vileišis, J. 1939. Ar reikalinga Kaunui naujieji Rotušès rūmai, Lietuvos žinios 22(5887): 5. 


\section{MANIFESTATIONS OF ARCHITECTURAL POLICY IN THE LITHUANIAN PRESS DURING INTERWAR PE- RIOD (1918-1940): BETWEEN REPRESENTATION AND SOCIAL JUSTICE}

\section{Petrulis}

Abstract. The paper concentrates on architectural discourse of the interwar period (1918-1940) of Lithuania. The main objective of the paper is to represent the history of the Lithuanian architectural thought of the period through analysis of the interwar press. Due to a wide scope of the problem the paper is devoted to one of the major problems of architectural theory - relation of policy/power and space. Following publications in the press, a few dominant aspects of the problem were distinquished: representation of the state (as an exemplar element of global political ideology), and issues of social housing (as illustration of local, towards practical decisions oriented policy). It is discovered that the dominant theoretical position concerning the matters of spatial representation is discussions on "national style". While the socio-political discourse of Modern Movement mainly concentrates on discussions about "social housing colonies".

Keywords: interwar period, theory of architecture, architectural policy, national style, social housing, Modern Movement.

\section{VAIDAS PETRULIS}

Doctor of the Humanities (arch), Kaunas University of Technology, Institute of Architecture and Construction., Tunelio g. 60, LT-44405 Kaunas, Lietuva. E-mail: vaidas_petrulis@yahoo.com

Research worker, Institute of Architecture and Construction of Kaunas University of Technology (Sector of History and Heritage of Architecture). Publications: author of a series of research papers and conference presentations on soviet and interwar Lithuanian architecture and architects. Member of ICOMOS and DOCOMOMO. Teaching: history of modern architecture, Vytautas Magnus University. Research interests: history and theory of the $20^{\text {th }} \mathrm{c}$. architecture, soviet culture. 